\title{
Determination of the phosphorylated neurofilament subunit NF-H (pNF-H) in cerebro-spinal fluid as biomarker in acute traumatic spinal cord injuries
}

\author{
Dozarea neurofilamentelor fosforilate (subunitatea pNF-H) în LCR ca \\ biomarker în traumatismul vertebro-medular acut
}

\author{
Didona Ungureanu ${ }^{1}$, Ștefan Mircea Iencean ${ }^{2 *}$, Cristina Dimitriu ${ }^{1}$, \\ Andrei Ștefan Iencean ${ }^{3}$, Alexandru Tascu ${ }^{4}$ \\ 1. Biochemistry Department "GrT Popa" University of Medicine and Pharmacy Iasi; \\ 2. Neurosurgery Department "GrT Popa" University of Medicine and Pharmacy Iasi; \\ 3. Neurosurgery Department "Prof Dr N Oblu” Emergency Clinic Hospital Iasi; \\ 4. Neurosurgery Department, "Carol Davila" University of Medicine and Pharmacy Bucharest
}

\begin{abstract}
Study objective. The objective of this study was to measure the phosphorylated neurofilament subunit NF-H $(p N F-H)$ in cerebro-spinal fluid of patients with spinal cord injury and to determine the correlation between the pNF-H levels and the severity of the injury. Materials and methods. The study included 15 subjects with acute traumatic spinal cord injury: eight patients with complete spinal cord injury (SCI) and seven patients with incomplete SCI. All patients were classified according to the American Spinal Injury Association impairment scale (ASIA) and all patients underwent surgery during the first 24 hours (decompression, stabilization). We measured daily the heavy phosphorylated neurofilament subunit ( $p N F-H)$ concentration by sandwich ELISA test in CSF in all patients and we correlated the values of $p N F-H$ with the clinical evolution. Results. For all patients with SCI pNF-H was detectable in CSF samples and the values were different in the cases of complete SCI toward the cases of incomplete $S C I$ and the cerebro-spinal pNF-H level was more elevated in cases of complete SCI. The level of CSF pNF-H was ten to a hundred times higher in complete SCI than the level of CSF pNF-H in cases with incomplete SCI, where the level of this biomarker was close to normal. The patients with a favorable neurological evolution after treatment had a specific pattern of daily values of pNF-H: a sudden increase up to a maximum value then a progressive decrease until normal. The maximum values were different in each case, from 10 times up to 170 times higher than the normal. Conclusion. The phosphorylated form of the high-molecular-weight neurofilament subunit NF-H (pNF-H) in cerebro-spinal fluid can be a specific biomarker for spinal cord injury and it can distinguish the severity of SCI. pNF-H is a predictive biomarker because of its values pattern can show the reducing or stopping of the secondary lesion and the favorable result.
\end{abstract}

Keywords: biomarker, cerebro-spinal fluid, phosphorylated neurofilament subunit NF-H, spinal cord injury

*Corresponding author: Ștefan Mircea Iencean, “Gr. T. Popa” University of Medicine and Pharmacy Iași, România, e-mail: mirceasteffan@yahoo.com 


\section{Rezumat}

Obiectivul studiului. Obiectivul acestui studiu a fost dozarea neurofilamentelor fosforilate (subunitatea pNF-H) în lichidul cefalorahidian al pacienţilor cu leziuni traumatice ale măduvei spinării și stabilirea unei corelații intre valoarea pNF-H și gravitatea leziunilor medulare. Material și metode. Studiul a inclus 15 pacienți cu leziuni traumatice acute medulare: opt pacienți cu leziuni medulare complete și șapte pacienți cu leziuni medulare incomplete. Gravitatea leziunilor medulare a fost apreciată folosind scala ASIA (American Spinal Injury Association scale) și la toti pacientii s-a aplicat tratamentul chirurgical în primele 24 de ore (decompresiune medulară și stabilizare vertebrală). S-a facut determinarea zilnică a pNF-H din LCR folosind testul ELISA specific şi am corelat aceste valori cu evoluția clinică. Rezultate. Subunitatea pNF-H a fost evidenţiată în LCR la toţi pacienţii cu traumatisme acute vertebro-medulare și valorile au fost diferite în cazurile leziunilor medulare complete faţa de leziunile incomplete. Nivelul pNF-H din LCR a fost de zece până la o sută de ori mai mare în leziunile medulare complete fata de cazurile cu leziuni incomplete, unde nivelul acestui biomarker a fost aproape normal. Pacienţii cu o evoluție neurologică favorabilă după tratament au avut un model specific al valorilor zilnice de pNF-H: o creștere bruscă până la o valoare maximă apoi o scădere progresivă până la normal. Valorile maxime au fost diferite în fiecare caz, de 10 ori până la 170 de ori mai mari faţă de normal. Concluzii. Forma fosforilată a subunității neurofilamentelor cu greutate moleculară mare $\mathrm{pNF-H}$ din lichidul cefalorahidian poate fi un biomarker specific pentru leziunile acute traumatice ale măduvei spinării corelat cu severitatea leziunilor medulare. $\mathrm{pNF-H}$ pare a fi un biomarker predictiv deoarece modelul evolutiv al valorilor sale arată reducerea sau blocarea leziunilor medulare secundare și se corelează cu evoluţia favorabilă clinică.

Cuvinte cheie: biomarker, lichid cefalorahidian, neurofilamente fosforilate (subunitatea pNF-H), traumatism vertebro-medular

\section{Received: $9^{\text {th }}$ January 2014; Accepted: $7^{\text {th }}$ August 2014; Published: $7^{\text {th }}$ September 2014.}

\section{Introduction}

Complete traumatic spinal cord injury leads to paraplegia or tetraplegia depending on the level of injury. It is estimated that many traumatic spinal cord injuries are initially incomplete and the secondary damage completes destruction of the spinal cord in the next period $(1,2)$. It has been accepted that the severity of the primary mechanical insult causes the amplitude of the secondary damage. Primary spinal cord injury due to trauma can be: contusion, compression, laceration, shearing and even distraction with transection of the spinal cord, and also dura mater injury. All these mean a direct injury of the neurons, axons and blood vessels. Immediate after the injury event, the secondary injury mechanisms begin and the spinal cord lesions consist of hemorrhages in the central grey matter, spinal cord edema and vasospasm with hypoperfusion of the spinal cord causing tissue hypoxia and lead to ionic imbalance, occurrence of free radicals, release of glutamatergic excitotoxicity, lipid peroxidation etc. Therefore the damage of neurons, fibers and supporting cells continues to progress for several days, even weeks, and leads to the death of neurons and the interruption of the axonal tracts. This secondary injury extension of the spinal cord caused by inflammation, hypoxia and excitotoxicity can be reduced by an early efficient therapy. (3) We cannot act on the primary lesion, but the secondary damage can be stopped or reduced and it is assumed that such interventions are efficient if early so there is a need to act with neuroprotection in the very acute stage (4); also the therapeutical answer is different in patients depending of the severity of the injury (5). For this it is necessary to know the type and the evolution phase of the secondary lesions: complete lesions with destruction of nerve tissue or spinal cord injury with potential recovery, to act with neuroprotective medication to reduce the extent of neural damage and even to act with possible neural regeneration factors. 
The clinical examination using the American Spinal Injury Association (ASIA) motor scores cannot be considered reliable immediately following injury (because of the spinal shock, attendant injuries, unstable conditions of patient, alcohol or drugs etc.) (6), and it must be repeated, but it offers only a static clinical state and no dates about evolution (7). Also the non-invasive imaging techniques as CT or MRI, even functional MRI, tractography or the recent structural volumetric and microstructural MRI protocols (8) from the site of spinal cord injury, offer only static images of the stage of the lesion and not an accurate prediction of the severity of spinal cord injury and about the evolution $(9,10)$. Also an early MRI examination needs a stable patient and the scanning time is long. Therefore we need an approach to accurate evaluate the spinal cord damage in the acute stage and these diagnostic tests must show also the further evolution as a prediction of functional outcome. These diagnostic tests may be the measurements of the concentration of a specific proteins in blood or in the cerebrospinal fluid (11-14) correlated with the nervous tissue injury. These are biomarkers whose presence is indicative of lesion and they evaluate the pathologic processes during the spinal cord injury.(15-17). Several studies have analyzed more biomarkers for the nervous tissue injury (c-Tau, myelin basic protein - MBP, neuron-specific enolase - NSE, glial fibrillar acidic protein - GFAP etc.), but some of these studies reported a new biomarker, the phosphorylated form of the high-molecular-weight neurofilament subunit NF-H (pNF-H), which is a part of cytoskeletal proteins in axon fibers (18-21). Neurofilaments are the major cytoskeletal components in axon fibers and they consist of three major subunits of neurofilaments on the basis of molecular weight: heavy (NF- H, 200kDa), medium (NF-M,150kDa) and light (NF-L, 68kDa) subunits (22). Dephosphorylation and proteolysis of phosphorylated neurofilaments occurs after axonal injury (23) and the stability of neu- rofilaments reduces (24) and in animal experiments increased serum levels of neurofilaments appeared at some hours after spinal cord injury (18). In a recent report Hayakawa et al. presented a correlation between plasma pNF-H level and the severity of patients with SCI, therefore the phosphorylated form of the high-molecular-weight neurofilament subunit NF-H (pNF-H) may be a prognostic biomarker for SCI $(21,25)$. This would allow for early indications of neural regeneration therapy and it creates preconditions for individualizing the care of patients with spinal cord injury. Personalizing the care of patients with SCI means ensuring immediately after the diagnosis of SCI, the determination of the type of local spinal cord lesion and treatment required for each patient.

For this it is necessary to know the type and the evolution phase of the secondary lesions: complete lesions with destruction of nerve tissue or spinal cord injury with potential recovery, to act with neuroprotective medication to reduce the extent of neural damage and even to act with possible neural regeneration factors.

The aim of this study was to measure pNF-H in the cerebro-spinal fluid of patients with SCI, because the CSF level of pNF-H has not been evaluated in human patients with SCI, and to determine the correlation between these pNF-H levels and the severity of the injury.

\section{Materials and Methods}

We performed a prospective study of acute traumatic spinal cord injury patients, cervical SCI and thoracic SCI in the last three years, including 8 patients with complete SCI and 7 patients with incomplete SCI. All patients were classified according to the American Spinal Injury Association impairment scale (ASIA): eight patients as A grade with tetraplegia, paraplegia with brachial diparesis or paraplegia and seven patients with incomplete lesions: B, C or D grade, with tetraparesis, brachial diparesis and 
normal gait or paraparesis, depending on the spinal cord injury level. Diagnosis was established by plain radiographs supplemented with $\mathrm{CT}$ and /or MRI for poorly visualized or suspicious areas. Cerebral CT and MRI excluded simultaneous traumatic brain injuries and other chronic CNS pathologies that can lead to presence of pNF-H in CSF. One patient had important respiratory disorders and cardiovascular instability and an unfavorable evolution with death at three days, without surgery. All other patients underwent surgery during the first 24 hours with anterior approach for cervical spine and posterior approach for thoracic spine with decompression, reduction and anterior arthrodesis with plate fixation for cervical spine and posterior stabilization in the thoracic spine. Table I present the characteristics of all patients. We measured the heavy phosphorylated neurofilament subunit (pNF-H) concentration by standard sandwich ELISA test in CSF in all patients and we cor- related the values of pNF-H with the clinical evolution; we also measured the normal values in samples obtained by lumbar puncture from individuals without neurologic disorders. We used a sandwich enzyme immunoassay ( EIA) which measures pNF-H in CSF [Phosphorylated Neurofilament (pNF-H) Sandwich ELISA Kit, MILLIPORE,US]. Cerebro-spinal fluid samples of 3 $\mathrm{ml}$ were collected at 6 to 12 hours after trauma before surgery and daily after surgery till discharge or until death (one case with unfavorable outcome), then frozen and stored until assay. The period of dosing for pNF-H was different due to the different duration of hospitalization for each patient or in some cases for subjective reasons ( patient or relatives no longer accepted repeated lumbar punctures). All the patients or their relatives, in relation to each situation, gave their written informed consent before the start of the study and the hospital ethics committee approved the study protocol.

Table I. Patient characteristics

\begin{tabular}{|c|c|c|c|c|c|c|c|c|c|}
\hline Case & Age & Sex & $\begin{array}{l}\text { Level of } \\
\text { injury }\end{array}$ & $\begin{array}{c}\text { Mechanism } \\
\text { of injury }\end{array}$ & $\begin{array}{l}\text { ASIA } \\
\text { initial }\end{array}$ & $\begin{array}{c}\text { Steroid } \\
\text { treatment }\end{array}$ & $\begin{array}{c}\text { Surgery } \\
\text { decompression } \\
\text { instrumentation }\end{array}$ & $\begin{array}{l}\text { Follow-up } \\
\text { period }\end{array}$ & $\begin{array}{l}\text { ASIA } \\
\text { final }\end{array}$ \\
\hline 1 & 50 & $\mathrm{M}$ & C5C6 & MVA & A & yes & exit & 3 days & - \\
\hline 2 & 53 & $\mathrm{M}$ & $\mathrm{C} 4 \mathrm{C} 5$ & FW & A & yes & yes & 1 year & A \\
\hline 3 & 42 & $\mathrm{M}$ & $\mathrm{C} 7$ & $\mathrm{FW}$ & A & no & yes & 2 years & B \\
\hline 4 & 21 & $\mathrm{M}$ & T11 & $\mathrm{FS}$ & A & no & yes & 18 months & A \\
\hline 5 & 34 & $\mathrm{~F}$ & $\mathrm{C} 5 \mathrm{C} 6$ & FW & A & yes & yes & 18 months & $\mathrm{C}$ \\
\hline 6 & 32 & $\mathrm{M}$ & $\mathrm{C} 4$ & MVA & A & no & yes & 1 year & A \\
\hline 7 & 27 & $\mathrm{~F}$ & T9T10 & MVA & A & no & yes & 1 year & $\mathrm{B}$ \\
\hline 8 & 24 & $\mathrm{M}$ & C6C7 & FW & A & yes & yes & 2 years & $\mathrm{C}$ \\
\hline 9 & 33 & $\mathrm{~F}$ & $\mathrm{C} 4 \mathrm{C} 5$ & $\mathrm{FS}$ & $\mathrm{C}$ & no & yes & 1 year & $\mathrm{D}$ \\
\hline 11 & 47 & $\mathrm{~F}$ & T10T11 & $\mathrm{FS}$ & $\mathrm{C}$ & no & yes & 18 months & $\mathrm{E}$ \\
\hline 12 & 42 & $\mathrm{M}$ & T6 & MVA & B & no & yes & 1 year & $\mathrm{C}$ \\
\hline 13 & 37 & $\mathrm{M}$ & $\mathrm{C} 5$ & FW & $\mathrm{C}$ & no & yes & 1 year & $\mathrm{D}$ \\
\hline 14 & 39 & $\mathrm{M}$ & $\mathrm{C} 5 \mathrm{C} 6$ & FW & $\mathrm{C}$ & no & yes & 1 year & $\mathrm{D}$ \\
\hline 15 & 56 & $\mathrm{M}$ & C6 & FW & B & yes & yes & 10 months & $\mathrm{C}$ \\
\hline
\end{tabular}

1.Abbreviations: MVA, motor vehicle accident; FW, fall from farm or hay wagon or from horse cart; FS, fall down the stairs.

2.ASIA Impairment Scale: A = Complete. (No sensory or motor function); B = Sensory Incomplete. (Sensory but not motor function is preserved below the neurological level); $\mathrm{C}=$ Motor Incomplete. (Motor function preserved below the neurological level, muscle grade less than 3); $\mathrm{D}=$ Motor Incomplete.(Motor function is preserved below the neurological level muscle grade $>3$.); $\mathrm{E}=\mathrm{Normal}$ 


\section{Results}

The results are presented in the Table $I$ and Table II, both the patients' characteristics and the values of pNF-H for each patient in relation with the clinical evolution. The notation in the table corresponds to the following situations: notation C4C5, or T9T10 or similar for level of vertebral injury, means a luxation between the two vertebrae and the notation of a single vertebra, as C7 or T11 or similar, corresponds to a burst fracture of this vertebra, with a subsequent spinal cord injury (Figure 1).

There were 8 patients with complete spinal cord injury and among these as gender distribution there were only two women, therefore an evidence of male dominance, related to the type of activity; and in the group of incomplete SCI there were only two women, too. Age distribution (Table I) demonstrated the involvement of the working ages both in complete and in incomplete spinal cord injury groups. One of the 8 patients with complete SCI (C5C6 complete SCI) had an unfavorable evolution because of important cardiovascular and respiratory disorders with death at three days after his motor vehicle accident. The other seven patients with complete spinal cord injury underwent surgery during the first 24 hours and after the follow up period of $1-2$ years three patients rest at A grade and four patients have improved to a superior grade on the ASIA scale. In the group with incomplete spinal cord injury, all patients underwent surgery with decompression, reduction and stabilization during the first 24 hours and have improved at the follow-up period.

For all patients with SCI pNF-H was detectable in CSF samples and values were different in the cases of complete SCI compared to cases of

Table II. Values of pNF-H in cerebro-spinal fluid (ng/mL)

\begin{tabular}{|c|c|c|c|c|c|c|c|c|c|c|c|c|c|c|}
\hline $\mathbf{N o} \backslash \mathbf{A S I A}$ & Level & $6 \mathrm{~h}$ & $24 \mathrm{~h}$ & $48 \mathrm{~h}$ & $72 \mathrm{~h}$ & $\begin{array}{c}\text { Day } \\
4\end{array}$ & $\begin{array}{c}\text { Day } \\
5\end{array}$ & $\begin{array}{c}\text { Day } \\
6\end{array}$ & $\begin{array}{c}\text { Day } \\
7\end{array}$ & $\begin{array}{c}\text { Day } \\
8\end{array}$ & $\begin{array}{c}\text { Day } \\
9\end{array}$ & $\begin{array}{c}\text { Day } \\
10\end{array}$ & $\begin{array}{c}\text { Day } \\
11\end{array}$ & $\begin{array}{c}1 \mathrm{y} / 18 \mathrm{~m} \\
\text { or } 2 \mathrm{y}\end{array}$ \\
\hline Case $1 \mathrm{~A}$ & C5C6 & 9.3 & 10.9 & 9.3 & & & & & & & & & & exit \\
\hline Case 2 A & $\mathrm{C} 4 \mathrm{C} 5$ & 4.5 & 5.5 & 5.9 & 6.5 & 5.6 & & & & & & & & A \\
\hline Case $3 \mathrm{~A}$ & $\mathrm{C} 7$ & 1.17 & 178,2 & 121.2 & 86.4 & 75.6 & 67.2 & 59.4 & 43.2 & 24.6 & 44.4 & 18 & 17.4 & $\mathrm{~B}$ \\
\hline Case $4 \mathrm{~A}$ & T11 & 0.83 & 15.6 & 98.4 & 115.8 & 131.4 & 89.4 & 73.4 & 63 & 58.2 & 43.2 & 21.6 & 8.4 & $\mathrm{~A}$ \\
\hline Case $5 \mathrm{~A}$ & C5C6 & 0.6 & 163.2 & 116.4 & 69 & 33.6 & 9.6 & & & & & & & $\mathrm{C}$ \\
\hline Case $6 \mathrm{~A}$ & $\mathrm{C} 4$ & 0.99 & 34.5 & 57 & 64.2 & 60 & 45 & 33 & & & & & & $\mathrm{~A}$ \\
\hline Case $7 \mathrm{~A}$ & $\begin{array}{l}\text { T9T10 } \\
\end{array}$ & 0.62 & 25.2 & 29.4 & 29.4 & 24.6 & 19.8 & 9.6 & 4.5 & & & & & B \\
\hline Case $8 \mathrm{~A}$ & C6C7 & 0.6 & 9.6 & 8.4 & 3.6 & 1.2 & 0.82 & & & & & & & $\mathrm{C}$ \\
\hline Case $9 \mathrm{C}$ & C4C5 & 0.9 & 1.16 & 0.9 & 0.6 & & & & & & & & & $\mathrm{D}$ \\
\hline Case 10 D & T11 & 0.81 & 0.83 & 0.83 & 0.6 & & & & & & & & & $E$ \\
\hline Case $11 \mathrm{C}$ & T10T11 & 0.9 & 1.16 & 0.62 & 0.2 & & & & & & & & & $\mathrm{E}$ \\
\hline Case $12 \mathrm{~B}$ & T6 & 0.6 & 3.6 & 1.17 & 0.8 & 0.6 & & & & & & & & $\mathrm{C}$ \\
\hline Case $13 \mathrm{C}$ & $\mathrm{C} 5$ & 0.88 & 0.889 & 0.62 & 0.6 & 0.2 & & & & & & & & $\mathrm{D}$ \\
\hline Case $14 \mathrm{C}$ & C5C6 & 0.99 & 0.94 & 0.95 & 0.81 & 0.6 & & & & & & & & $\mathrm{D}$ \\
\hline Case $15 \mathrm{~B}$ & C6 & 0.86 & 0.99 & 0.86 & 0.62 & & & & & & & & & $\mathrm{C}$ \\
\hline Normal 1 & - & 0 & 0 & & & & & & & & & & & E \\
\hline Normal 2 & - & 0.2 & 0.2 & & & & & & & & & & & $\mathrm{E}$ \\
\hline Normal 3 & - & 0.1 & 0.1 & 0.1 & & & & & & & & & & $\mathrm{E}$ \\
\hline Normal 4 & - & 0 & 0 & & & & & & & & & & & $E$ \\
\hline Normal 5 & - & 0.6 & 0.62 & 0.6 & & & & & & & & & & $E$ \\
\hline Normal 6 & - & 0 & 0 & & & & & & & & & & & $\mathrm{E}$ \\
\hline
\end{tabular}




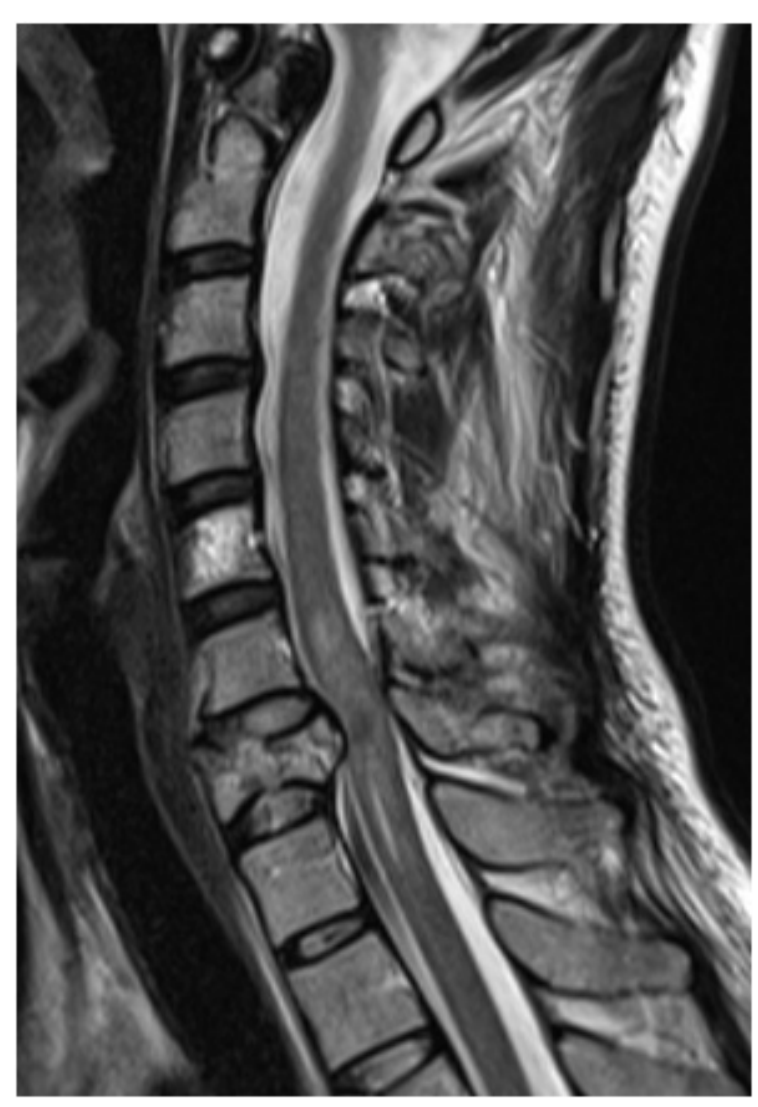

Figure 1. Burst fracture of $\mathrm{C} 7$ vertebral body compressive and complete SCI

incomplete SCI; the cerebro-spinal pNF-H level was more elevated in cases of complete SCI. The normal level of CSF pNF-H was determined in samples obtained by lumbar puncture from six individuals without neurologic disorders and these values were similar to the normal level set by Petzold and Shaw in 2007: $0 \mathrm{ng} / \mathrm{mL}$ to 0.9 ng/mL. (26).

We found the level of CSF pNF-H to be ten to a hundred times higher in complete SCI than the level of CSF pNF-H in cases with incomplete $\mathrm{SCI}$, where the level of this biomarker was close to normal levels. Therefore the CSF pNF-H level was in accordance with the severity of the injury. Also we found that the increased level of CSF pNF-H remained elevated up to five to twelve days after injury.
Figure 2 illustrates the graphical form of the values of CSF pNF-H for four cases of complete SCI and for a normal case, and allows the correlation with the clinical evolution and the improvement or stationary situation. The daily values of CSF pNF-H in case 2 (C4C5 spinal cord injury level), which remained neurological stationary after treatment, were five to six times higher than normal and had a plateau evolution with a quasi-stationary level of pNF-H values. The daily values of CSF pNF-H in case 4 (T11 burst fracture), which remained neurological stationary after treatment, had a progressive increase up to more than one hundred times compared with normal values and then, after the peak of $131.4 \mathrm{ng} / \mathrm{ml}$, followed by a progressive decrease until normal. Cases 3 and 7 had a favorable neurological evolution after treatment and had different patterns of daily values of NFP-H: a sudden increase up to a maximum value then a progressive decrease until normal. Cases 5 and 8 had the same type of pattern of daily values of NFP-H and also had a favorable neurological evolution after treatment. The maximum values were different in each case, from 10 times up to 170 times higher than normal. The seven cases with incomplete lesions with favorable outcome after treatment had much lower values of pNF-H, closer to normal, and they had a curve of the values of pNF-H with a sudden increase followed by a progressive decline to normal in a short period of time. In all cases of complete or incomplete spinal cord injury the elevated values of $\mathrm{pNF}-\mathrm{H}$ in cerebro-spinal fluid stayed increased for different periods of time, probably due to individual variations but possibly correlated with the severity of injury.

\section{Discussion}

Several published reports concerning the nervous tissue markers as indicators of tissue injury in central nervous system (CNS) damage 


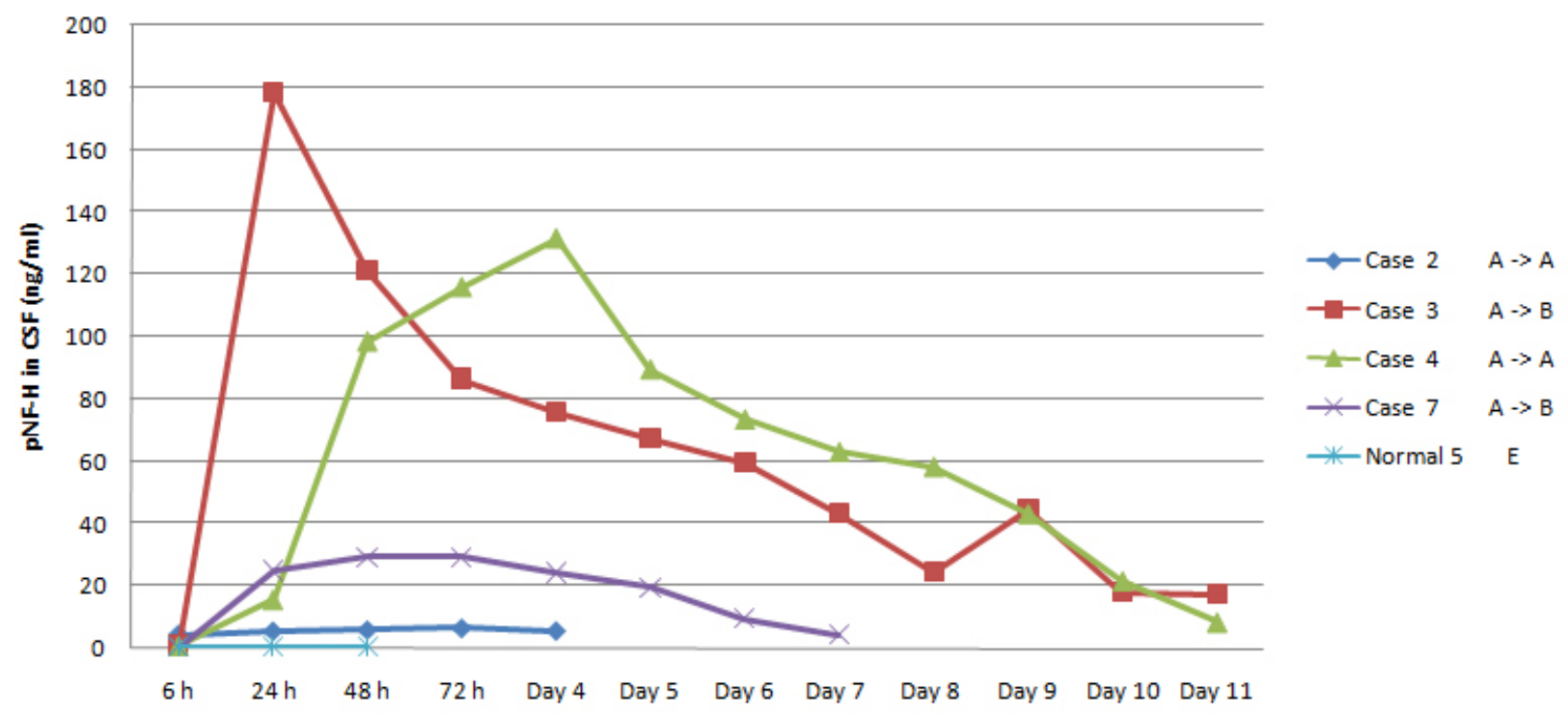

Figure 2. The graphical form of the daily CSF pNF-H values for cases 2, 3, 4 and 7 of complete SCI with three specific pattern of daily values of pNF-H (vertical axis - values of pNF-H ng/mL; horizontal axis daily evaluation of CSF pNF-H values):

- case 2: neurological stationary - a plateau of pNF-H values (increased values higher five or six times of normal)

- case 3: favorable outcome - a sudden increase up to a maximum value then a progressive decrease until normal (the peak was different in each case, hundreds of times higher than the normal)

- case 4: neurological stationary - progressive increasing up to a peak and then followed by a progressive decrease until normal values (the peak was tens of times higher than the normal)

- case 7: favourable outcome - a sudden increase, then a progressive decrease, with lower pNF-H values than case 3.

- normal case: normal CSF pNF-H values.

have indicated that the levels of specific proteins in the CSF and serum may be used as biomarkers. Concerning the acute traumatic spinal cord injury in humans, there are few studies on the value of biomarkers, but there are several studies on biomarkers in animals with SCI. The report of Guez et al., 2003, analyzed the entire protein complex of neurofilament protein (NFL) levels in CSF after trauma to the cervical spine in human. They found significantly increased levels of NFL in all patients with tetrapareses than those with incomplete injuries and they asserted the possibility to quantify the degree of the SCI by assessing nervous tissue markers in CSF.(27)

In this prospective study we analyzed the values of the phosphorylated form of the high-molecular-weight neurofilament subunit NF-H
(pNF-H) as a specific marker for axonal injury in the cerebrospinal fluid samples from eight patients with complete spinal cord injury and from seven patients with incomplete spinal cord injury. Cerebral CT and MRI excluded both acute brain injuries and chronic CNS pathologies, as multiple sclerosis, amyotrophic lateral sclerosis etc. that can lead to presence of pNF-H in CSF. For all patients the increased pNF-H levels were detectable in CSF samples immediately after trauma and the values have grown to a peak or increased to a plateau and then decreased. The values were different in the cases of complete SCI toward the cases of incomplete SCI and the cerebro-spinal pNF-H levels were more elevated in cases of complete SCI. The study of Hayakawa et al. analyzed the plasma pNF-H measure- 
ments from patients with cervical SCI and they found detectable levels of pNF-H and that the pNF-H levels were significantly greater in complete cervical SCI compared with patients with incomplete cervical SCI. Also they found an increased level of pNF-H up to 21 days after injury (21).

Our results differ from those of Hayakawa et al. but are similar with the experimental results in animals: the concentration of pNF-H in the rat has its peak at 3 days and returns to the baseline 14 days after injury (18). We found an initial increase after trauma and then the values have grown to a peak or they increased to a plateau and then decreased to normal values at five to $12-14$ days after injury, probably due to individual variations but possibly correlated with the severity of injury. Hayakawa et al. stated that the prolonged elevation of plasma pNF-H suggests the involvement of a continuous axonal degeneration, or secondary axonal damage and the pNF-H level in blood represents the amount of axonal degeneration as a "hole"( 21).

We found in our study some patterns of increased pNF-H levels strongly correlated with the clinical evolution of patients with complete spinal cord injury. The cases with a favorable neurological evolution after early surgery in complete spinal cord injury had a specific pattern of daily values of pNF-H: a sudden increase up to a maximum value then a progressive decrease until normal; the peak was different in each case, from 10 times up to 170 times higher than the normal. There is the same type of the pattern for the values of pNF-H in the incomplete spinal cord injury with favorable outcome, but with smaller values of pNF-H. We found two patterns in cases with unfavorable outcome or neurological stationary after the same treatment: an increase to a plateau of $\mathrm{pNF}-\mathrm{H}$ values, also with increased values five or ten times higher than normal, and the second unfavorable pattern had a progressive increase up to a peak and then was followed by a progressive decrease to normal values; the peak was a hundred times higher than normal values. With respect to these types of $\mathrm{pNF}-\mathrm{H}$ patterns we assume that in cases with favorable evolution after the initial increase the progressive decrease of pNF-H values, without extension of increased values in plateau or without of a second peak, shows a reduction or even stop of the secondary lesion with evident effect on the favorable evolution of the spinal cord injury.

Concerning the pharmacological neuroprotective therapy, at present only metylpredonisolone is in clinical use ( e.g. methylprednisolone given within 8 hours of the injury), but in our study the analysis of steroid treatment correlated with early surgery and the values of pNF-H did not show a clear result on the improvement of patients with spinal cord injury.

There are more structural proteins reported as possible biomarkers in spinal cord injury asneuroinflammatory-linked cytokines, cleavedTau, microtubule-associated protein 2, myelin basic protein (MBP), neuron-specific enolase, $\mathrm{S} 100 \beta$, glial fibrillar acidic protein and neurofilaments etc. in several experimental or human studies. But some of these were not significantly elevated in patients with SCI compared with patients without any neurologic lesions (cleavedTau) (28) or the detection of MBP in the CSF is lower (29) or some are also found in other cells, such as adipocytes (S100ß) (30). Also, there are few clinical studies for the majority of them or there are problems related to their accessibility. More studies about biomarkers in spinal cord injury are needed, and these biochemical marker should have some of the following characteristics: the biomarker must be specific to CNS injury, it must describe the progression of the lesion or recovery and to confirm the results obtained by other methods and it should predict a serious injury by an early determination. Also, these bio- 
markers must be inexpensive, easy to use and reproducible binding.

We believe that the phosphorylated form of the high-molecular-weight neurofilament subunit NF-H (pNF-H) meets now these conditions and pNF-H could be a specific marker for spinal cord injury in the cerebrospinal fluid samples. CSF pNF-H is specific to axonal injury, therefore to the spinal cord injury, the values of pNF-H describe early the severity of spinal cord injury and these values have a characteristics pattern consistent with the progression of the disease and pNF-H values confirm the results of other investigations (spinal MRI, tractography). The CSF pNF-H measurement in patients with $\mathrm{SCI}$ is relatively inexpensive, easy to use and the results are reproducible. Our results are similar with the results of Guez in cervical spinal cord injury, with the experimental researches in animals and there are also similarities in most results with the report of Hayakawa et al., but they worked with blood pNF-H samples (21).

In conclusion, for the patients without traumatic brain injury or degenerative diseases of the nervous system, we assume that the phosphorylated form of the high-molecular-weight neurofilament subunit NF-H (pNF-H) can be a specific biomarker for spinal cord injury and this study is the first report of CSF pNF-H measurement in patients with complete and incomplete spinal cord injury. CSF pNF-H is a biomarker that can distinguish the severity of SCI and it is a predictive biomarker because of the CSF pNF-H values pattern can show the reducing or stopping of the secondary lesion and the favorable result. The CSF pNF-H values pattern in plateau or with latter peak complies with a progressive secondary lesion and therefore with an unfavorable result. These results are promising although there were only 15 patients in this study; the issue of biomarkers in spinal cord injury is extremely important and requires further research in this area.

\section{Acknowledgments}

This work is part of the grant: "Immediate neuroprotective therapy in acute traumatic spinal cord injury", grant number: PN-II-IDPCE-2011-3-0569, and was funded by the CNCS - UEFISCDI Romania.

The authors thank to the Editorial Team and to the Technical Integrity Editor for helping to correct this article.

\section{References}

1. Ramer LM, Ramer MS, Steeves JD. Setting the stage for functional repair of spinal cord injuries: a cast of thousands. Spinal Cord. 2005 Mar;43(3):134-61. DOI: 10.1038/sj.sc.3101715

2. Park E, Velumian AA, Fehlings MG. The role of excitotoxicity in secondary mechanisms of spinal cord injury: a review with an emphasis on the implications for white matter degeneration. Journal of Neurotrauma. 2004 Jun;21(6):754-74. DOI: 10.1089/0897715041269641

3. Hawryluk GW, Rowland J, Kwon BK, Fehlings MG. Protection and repair of the injured spinal cord: a review of completed, ongoing, and planned clinical trials for acute spinal cord injury. Neurosurgical Focus 2008;25(5):E14. DOI: 10.3171/FOC.2008.25.11.E14

4. Steeves JD, Lammertse D, Curt A, Fawcett JW, Tuszynski MH,Ditunno JF, et al. Guidelines for the conduct of clinical trials for spinal cord injury (SCI) as developed by the ICCP panel: clinical trial outcome measures. Spinal Cord. 2007 Mar;45(3):206-21. DOI: 10.1038/sj.sc.3102008

5. Houle JD, Tessler A. Repair of chronic spinal cord injury. Exp Neurol. 2003 Aug; 182(2): 247-60. DOI: 10.1016/S0014-4886(03)00029-3

6. Lubieniecka JM, Streijger F, Lee JHT, Stoynov N, Liu $\mathrm{J}$, et al. Biomarkers for Severity of Spinal Cord Injury in the Cerebrospinal Fluid of Rats. PLoS ONE. $2011 \mathrm{Apr}$ 29;6(4):e19247. DOI: 10.1371/journal.pone.0019247

7. de Vargas Ferreira VM, Varoto R, Azevedo Cacho ÊW, Cliquet A Jr. Relationship between function, strength and electromyography of upper extremities of persons with tetraplegia. Spinal Cord. 2012 Jan;50(1):28-32. DOI: $10.1038 / \mathrm{sc} .2011 .95$

8. Freund P, Weiskopf N, Ashburner J, Wolf K, Sutter R, Altmann DR, et al. MRI investigation of the sensorimotor cortex and the corticospinal tract after acute spinal cord injury: a prospective longitudinal study. Lancet Neurol. 2013 Sep;12(9):873-81. DOI: 10.1016/S14744422(13)70146-7

9. Yagi M, Ninomiya K, Kihara M, Horiuchi Y. Longterm surgical outcome and risk factors in patients with 
cervical myelopathy and a change in signal intensity of intramedullary spinal cord on Magnetic Resonance imaging. J Neurosurg Spine. 2010 Jan;12(1):59-65. DOI: 10.3171/2009.5.SPINE08940

10. Lammertse D, Dungan D, Dreisbach J, Falci S, Flanders A, Marino R, et al. Neuroimaging in traumatic spinal cord injury: an evidence-based review for clinical practice and research. J Spinal Cord Med. 2007;30(3):20514.

11. Mercier E, Boutin A, Lauzier F, Fergusson DA, Simard JF, Zarychanski R, et al. Predictive value of S-100 $\beta$ protein for prognosis in patients with moderate and severe traumatic brain injury: systematic review and meta-analysis. BMJ. 2013 Apr 4;346:f1757.

12. Cao F, Yang XF, Liu WG, Hu WW, Li G, Zheng XJ et al. Elevation of neuron-specific enolase and S-100beta protein level in experimental acute spinal cord injury. $\mathrm{J}$ Clin Neurosci. 2008 May;15(5):541-4. DOI: 10.1016/j. jocn.2007.05.014

13. Pouw MH, Hosman AJ, van Middendorp JJ, Verbeek MM, Vos PE, van de Meent H. Biomarkers in spinal cord injury. Spinal Cord. 2009 Jul;47(7):519-25. DOI: $10.1038 /$ sc. 2008.176

14. Kwon BK, Stammers AM, Belanger LM, Bernardo A, Chan D, Bishop CM et al. Cerebrospinal fluid inflammatory cytokines and biomarkers of injury severity in acute human spinal cord injury. J Neurotrauma. 2010 Apr;27(4):669-82. DOI: 10.1089/neu.2009.1080

15. Kamphuis W, Mamber C, Moeton M, Kooijman L, Sluijs JA, Jansen AH, et al. GFAP isoforms in adult mouse brain with a focus on neurogenic astrocytes and reactive astrogliosis in mouse models of Alzheimer disease. PLoS One. 2012 Aug;7(8):e42823. DOI: 10.1371/journal.pone.0042823

16. Maas MB, Furie KL. Molecular biomarkers in stroke diagnosis and prognosis. Biomark Med. 2009 Aug 1;3(4):363-83. DOI: $10.2217 / \mathrm{bmm} .09 .30$

17. Shinozaki K, Oda S, Sadahiro T, Nakamura M, Hirayama Y, Abe R, et al. S-100B and neuron-specific enolase as predictors of neurological outcome in patients after cardiac arrest and return of spontaneous circulation: a systematic review. Crit Care. 2009 Jul;13(4):R121. DOI: $10.1186 /$ cc7973

18. Shaw G, Yang C, Ellis R, Anderson K, Parker Mickle $\mathrm{J}$, Scheff $\mathrm{S}$ et al. Hyperphosphory-lated neurofilament NF-H is a serum biomarker of axonal injury. Biochem Biophys Res Commun. 2005 Nov 4;336(4):1268-77. DOI: 10.1016/j.bbrc.2005.08.252

19. Ueno T, Ohori Y, Ito J, Hoshikawa S, Yamamoto S, Nakamura $\mathrm{K}$ et al. Hyperphosphory-lated neurofilament NF-H as a biomarker of the efficacy of minocycline therapy for spinal cord injury. Spinal Cord. 2011 Mar;49(3):333-6. DOI: 10.1038/sc.2010.116

20. Boylan KB, Glass JD, Crook JE, Yang C, Thom- as CS, Desaro P, et al. Phosphorylated neurofilament heavy subunit (pNF-H) in peripheral blood and CSF as a potential prognostic biomarker in amyotrophic lateral sclerosis. J Neurol Neurosurg Psychiatry. 2013 Apr;84(4):467-72. DOI: 10.1136/jnnp-2012-303768

21. Hayakawa K, Okazaki R, Ishii K, Ueno T, Izawa N, $\mathrm{Y}$ Tanaka, et al. Phosphorylated neurofilament subunit NF-H as a biomarker for evaluating the severity of spinal cord injury patients, a pilot study. Spinal Cord. 2012 Jul;50(7):493-6. DOI: 10.1038/sc.2011.184

22. Petzold A. Neurofilament phosphoforms: surrogate markers for axonal injury, degeneration and loss. Journal of the Neurological Sciences 2005 Jun 15;233(12):183-98. DOI: 10.1016/j.jns.2005.03.015

23. Dileonardi AM, Huh JW, Raghupathi R. Differential effects of FK506 on structural and functional axonal deficits after diffuse brain injury in the immature rat. J Neuropathol Exp Neurol. 2012 Nov;71(11):959-72. DOI: 10.1097/NEN.0b013e31826f5876

24. Lee JY, Kim BJ, Sim G, Kim GT, Kang D, Jung JH, et al. Spinal cord injury markedly altered protein expression patterns in the affected rat urinary bladder during healing stages. J Korean Med Sci. 2011 Jun;26(6):81423. DOI: $10.3346 / \mathrm{jkms} .2011 .26 .6 .814$

25. Pouw MH, Kwon BK, Verbeek MM, Vos PE, van Kampen A, Fisher CG, et al. Structural biomarkers in the cerebrospinal fluid within $24 \mathrm{~h}$ after a traumatic spinal cord injury: a descriptive analysis of 16 subjects. Spinal Cord. 2014 Jun;52(6):428-33. DOI: 10.1038/ sc. 2014.26

26. Petzold A, Shaw G. Comparison of two ELISA methods for measuring levels of the phosphorylated neurofilament heavy chain. J of Immunological Methods. 2007 Jan 30;319(1-2):34-40. DOI: 10.1016/j. jim.2006.09.021

27. Guez M, Hildingsson C, Rosengren L, Karlsson K, Toolanen G. Nervous tissue damage markers in cerebrospinal fluid after cervical spine injuries and whiplash trauma. J Neurotrauma. 2003 Sep;20(9):853-8. DOI: $10.1089 / 089771503322385782$

28. Shiiya N, Kunihara T, Miyatake T, Matsuzaki K, Yasuda K. Tau protein in the cerebro-spinal fluid is a marker of brain injury after aortic surgery. Annals of Thoracic Surgery. 2004 Jun;77(6):2034-8. DOI: 10.1016/j.athoracsur.2003.12.057

29. Shen S, Loo RR, Wanner IB, Loo JA. Addressing the needs of traumatic brain injury with clinical proteomics. Clin Proteomics. 2014 Mar 28;11(1):11. DOI: 10.1186/1559-0275-11-11

30. Kiechle K, Bazarian JJ, Merchant-Borna K, Stoecklein V, Rozen E, Blyth B, et al. Subject-specific increases in serum S-100B distinguish sports-related concussion from sports-related exertion. PLoS One. 2014 Jan 8;9(1):e84977. DOI: 10.1371/journal.pone.0084977 